\title{
Cuba: characterization of two provinces with tourism potential for regional economic development. Case. Cienfuegos and Las Tunas
}

\section{Cuba: caracterización de dos provincias con potencial turístico para el desarrollo económico regional. Caso. Cienfuegos y Las Tunas} CAMELO-AVEDOY, José Octavio†*, RODRÍGUEZ-ALVAREZ, Nely, MERCADO-PUPO, Yoandris
and REYERO-NIETO, Roberto Fidel

Universidad Autónoma de Nayarit. Economy faculty. Mexico.

ID $1^{\text {st }}$ Author: José Octavio, Camelo-Avedoy / ORC ID: 0000-0002-5722-3032, CVU CONACYT ID: 99469

ID $1^{\text {st }}$ Co-author: Nely, Rodríguez-Alvarez / CVU CONACYT ID: 972018

ID $2^{\text {nd }}$ Co-author: Yoandris, Mercado-Pupo / CVU CONACYT ID: 1057191

ID $3^{\text {rd }}$ Co-author: Roberto Fidel, Reyero-Nieto / CVU CONACYT ID: 1057186

\begin{abstract}
In different territories of the world, especially in emerging countries, it has been considered that, taking advantage of the fact that they still conserve their natural attractions, make tourism a strategy to increase the economic activity of a certain region; It is not that the authors consider monoproductivity as a viable equation, but coupled with other economic dynamics, tourism can help to generate more income. This publication is located on the island of Cuba, in which the objective is to propose that two provinces become involved or increase their participation in activities oriented towards tourism, in consideration of their geographical location. A hypothetical approach has been used. Regarding tourism; Incorporating the province of Las Turnas and increasing activities in the province of Cienfuegos will generate the integration of a greater person to obtain an economic income. It has a descriptive scope. With an orientation on Regional Development.
\end{abstract}

\begin{abstract}
Resumen
En diferentes territorios del mundo, sobre todo en los países emergentes, se ha considerando que, aprovechando que aún conservan sus atractivos naturales, hacer del turismo una estrategia para incrementar la actividad económica de una determinada región; no es que los autores consideren la mono productividad como una ecuación viable, pero aunado a otras dinámicas económicas, el turismo puede coadyuvar a generar mayor derrama. La presente publicación se sitúa en la isla de Cuba, en la misma se tiene como objetivo proponer que dos provincias se involucren o incrementen su participación en actividades orientadas hacia el turismo, en consideración a su ubicación geográfica. Se ha utilizado un enfoque hipotético. Con respecto al turismo; el incorporar la provincia de Las Turnas e incrementar las actividades en la provincia de Cienfuegos, va a generar la integración de mayor persona a la obtención de un ingreso económico. Cuenta con un alcance descriptivo. Con una orientación sobre el Desarrollo Regional.
\end{abstract}

Actividad económica, Región, Turismo development. Case. Cienfuegos and Las Tunas. Journal of Social Researches. 2021. 7-20:13-28.

\footnotetext{
* Correspondence to Author (E-mail: ocameloa@uan.edu.mx)

$\dagger$ Researcher contributing as first author.
} 


\section{Introduction}

Tourism as a process has gone from being seen as a leisure activity and, in the case of monarchies, from traveling to see the world and cultivate, to an activity in which countries implement it as a way to attract investment and generate jobs. In their diversity of types of tourist activity, the less developed countries have a competitive advantage by still conserving a large part of their natural attractions, be it beach, hiking, cultural, among others.

The Caribbean island of Cuba, being in the Caribbean, has a number of tourist attractions, both sun and beach as well as hiking and cultural, since it is unknown to no one that they jealously conserve their cultural heritage and that it is a society with a high level of studies, in the total population. It is of these very particular characteristics that this document carries out an exploratory and descriptive study to consider that there are two territories that have a geo-strategic location, as well as tourist attractions, as well as to propose that their tourist detonation would generate a distribution of said activity and With this, generate regional enclaves points that in turn would increase the economic activity of the region, thereby helping an economic spill, attracting more resources to the State to act as a redistributor of the same, or integrating the population to said activity.

The document is divided into a first section entitled -Theoretical background- in which a brief, but substantial, debate of the concepts and categories that the document uses in its research is exposed. A following item has been named -Contextualization- in it a description is made of the geographical conditions that the island keeps in its distribution of tourist enclaves, as the main ones; A third section is called -Findings and discussion- which makes the proposal of two regional points that are considered with tourist potential and in turn a descriptive study of each of them is made. Finally, some conclusions are made.

\section{Theoretical Support}

The conceptualization of the economy has a complexity as so many definitions has said science.
For Marx (2010 [1867]) the economy is defined as "The economic structure of society is the real base on which the legal and political superstructure stands and to which certain forms of social consciousness correspond" (p.46), which is based on the production of the capitalist commodity and the social relation of production. For other authors such as Samuelson (1983), economics corresponds to the way in which "people and societies end up choosing, using money or not, the use of scarce productive resources that could have alternative uses to produce different goods and distribute them for their consumption, present or future, between different people and social groups. " (p. 2).

But what is agreed on, regardless of the economic-philosophical current that is embraced, is that there is a production process, and it is in that bosom, where a set of relationships are generated from it, be through the satisfaction of social needs or through supply and demand, without going into detail about whether it is labor-value or utility-value that defines prices or the same economic logic. The truth is that there is production and, in turn, there is the appropriation of nature and the accumulation of capital.

The Regional Economic Development approach has a period of time in debate and construction in which the different schools of economics seek to contribute; Of this, there is no single definition, although all of them address the economic part, they do so from their own concepts, categories and philosophy. When it comes to Economic Development, it must be differentiated from economic growth, they are not synonymous, although many authors imply the second as an element to achieve the first; In other words, for there to be economic development, there must be growth, but growth by itself does not imply development. "Economic growth is a sustained process over time in which levels of economic activity constantly increase [...] when an economy grows it becomes better quantitatively, when an economy develops it becomes better qualitatively" (Labruneé, 2018. P. 2.12). 
The region, from this perspective, it is not possible to observe it as a set of polygons, since "the region is a historical expression, a socio-economic construction, which is molded according to the contextual conditions of the historical moment of study of the region as a historical construction product of social, political and economic forces" (Gonzáles and Villa, 2002. P.89), is the concrete expression of the social relations of production, of the conditions of production, of the quantity necessary for the social production. Seen this way, the region is not in itself, but rather it is a function of the social and economic group that is gestated in a larger dimension, which involves the target region, and in turn, determines the construction of the contiguous region, which It must be, quantitatively or qualitatively, different, that is, heterogeneity as an element of the conceptual construction of the regional limit "the region thus appears, from this perspective, as the spatial expression of capitalist production relations through which it is transformed the geographical environment through the production process and where, at the same time, the transformation of the social classes themselves is generated" (Op. Cit. P. 92).

In this sense, economic regions have moments of expansion and others of contraction, depending on the economic historical moment, deviation either increasing or decreasing from its equilibrium level [...] the capitalist economy not only experiences fluctuating, undulating processes. This, at the same time, evolves, changes. In this evolutionary process his own level of equilibrium also changes. " (Sandoval, 2008, p. 157-158); that is, that, in accordance with what has been written in previous paragraphs, the region is dynamic, and its dynamism emanates from the economic behavior experienced in the sector or branch of the economy with which the productive orientation of the region in question is identified. "There are many processes that are considered in the rise and fall of economic activity that constitute economic cycles" (Heiler, 1969. p.79), in the same sense Sandoval (2008) writes "this does not mean that I think that development processes go on the one hand and fluctuations on the other, that both occur separately and independently in reality. My conception is different. The actual dynamics process is one. But this is not straight, nor does it appear as a simple ascending line." P (108).
Thus, there are moments of integration in moments of expansion, attracting their regional integration to the surrounding areas, integrating them into the productive orientation of the region in question. In another dimension, regional integration can be conceived from its local-global insertion, thus integrating itself into the international circuits of the circulation of social production. carry out the production of merchandise and agglomerate the labor force, in the form of city-regions, to satisfy the merchandise needs of society; It is the way in which from a dimension less than the national or supranational, social and capitalist relations are established for the production that aims at the social satisfaction of goods, be it for the social satisfaction of the region itself that produces the merchandise, or for other regions. These other regions can be integrated at the national or supranational level" (Camelo, 2017. P. 52)

From the perspective of the authors of the present, it is considered that nothing that has been written so far would have a meaning if it does not have as its objective the permeation of Social Benefit of the inhabitants of the region; It is external that the authors differ from leaving a priori that the benefit accumulates in a few people or firms, according to the dept. of legal file of the National Autonomous University of Mexico (UNAM, s / f) the Social Benefit is conceived as:

"Those benefits granted voluntarily by the employer, that is, that are not ordered by the legislation or by collective bargaining agreements or that improve those established by them [...] social benefits meet different types of human requirements, for this reason the $\mathrm{We}$ classify according to the need they satisfy. Thus we group them according to their content into 11 different categories: food, health, education, recreation and free time, transportation, additional remuneration or bonuses, insurance, tax debts, expected retirements and pensions, personal care "(s / n) in general The conjunction of better rates of the variables indicated, result in a better nutrition of the body and makes it more suitable to develop its potentialities; better options to have a social insertion with educational benefit; as well as improvement of time to enjoy non-work activities such as: exercising, family or social living, practicing arts, etc. 
Chiavenato (1999), for his part, has also presented his Social Benefit approach "which cannot be expressed -only- in monetary units, but in better working conditions, increased education or culture, reduction of pollution, etc. "Although in another publication he refines it in a more holistic way, according to the same author (2009) social benefits are certain perks and benefits that organizations grant, to all or part of their workers, in the form of additional payment for their work.

As can be seen, the social benefit approach goes in two directions: in which the organizations directly grant their workers as an extra condition to what is legally established; and, in the sense of that which is not represented in monetary units, but rather that which enhances people's abilities. But, in addition, from the perspective of the authors of this writing, it has to do with a regional dimension, not only business or organizational, in that the regional economic dynamics brings benefits to the region itself; that is, a Regional Social Benefit.

\section{Contextualization}

The Caribbean island of Cuba, has outstanding natural attractions to develop tourist activities, but at the same time, it has a historical-cultural legacy to make some localities join this dynamic. Of the above, known are tourist destinations such as: Havana, Old or colonial Havana, Vadadero beach, Holguín, Santiago de Cuba, Jardines del Rey, Trinidad, Cienfuegos, Baracoa, Viñales Valley, among others.

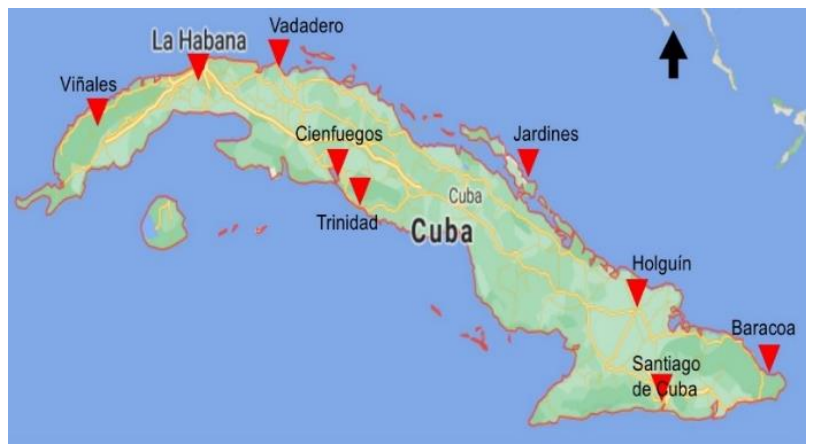

Figure 1 Main tourist enclaves of the Republic of Cuba Source: Own elaboration with data from: HiCuba and GoogleMaps
This geographical conformation of tourist enclaves of the Republic of Cuba, are distributed throughout the Island. But the two main ones, it is considered, are La Habanas and Playa Vadadero, with 10,000 and 14,000 rooms respectively (HiCuba, Op.Cit), of a total of 67,000 rooms available to all previously mentioned destinations. (Cuba Now, 2017); the total inhabitants of the island are estimated at 11.3 million (Expansion data, 2021. P s / n)

The general characteristics, on tourism, of the mentioned destinations are:

Havana, Old or colonial Havana. - "Havana is the capital of the country and almost since its foundation in 1519 it became the main commercial, economic and communications center due to its favored location in front of the Straits of Florida and a magnificent bay. Today the city is the main tourism plaza on the island based on its centennial history, the existence of magnificent quality beaches, an incredible cultural wealth in which the colonial center of Old Havana and its mixture of architectural styles stand out." (HiCuba, s / f).

Vadadero beach. - "It is the main and most beautiful Cuban spa, and also the best equipped on the island. It is located on the Hicacos peninsula on the north coast of the Matanzas province and $140 \mathrm{~km}(87.5 \mathrm{mi})$ east of the City of Havana with which it communicates by a highway of great visual beauty. It also has an international airport linked to several cities in North America and Europe”. (Op. Cit)

Holguin. - "The province of Holguín is currently considered the third most important Cuban tourist destination, with more than 4800 rooms in the hotel plant distributed mainly on Guardalavaca, Playa Esmeralda and El Pesquero beaches, all located on the North Coast of Holguín. Guardalavaca beach is the main tourist enclave of the destination known as North Coast of Holguín, in the eastern region of Cuba. Guardalavaca, surrounded by other small but idyllic beaches (Pesquero, Esmeralda, Turquesa and Don Lino), where there are several of the best and most luxurious hotels in Cuba". (Op. Cit.) 
Santiago de Cuba. - "Santiago de Cuba is the second city of Cuba and also the capital of the province of the same name, characterized by the interrelation of the main mountain range of the island, the Sierra Maestra and the Caribbean Sea. Santiago de Cuba is mountain and sea, the Caribbean Sea. The city, built in a hilly area next to the bay of the same name and with the Sierra Maestra as a backdrop, is very picturesque and full of beautiful physical settings and has an important historical and cultural heritage, to which interesting museums and colonial-era fortresses, squares and buildings, ruins of French coffee plantations and other attractions of all kinds, including beaches and semi-submerged remains of Almirante Cervera's fleet, living monuments reminiscent of the Spanish-CubanAmerican War of 1898" (Op. Cit.).

King's gardens. - "Los Jardines del Rey is an extensive hunt that extends to the north of the country off the coasts of the provinces of Ciego de Ávila and Camagüey. Cayo Coco and Cayo Guillermo are located here, two keys that have become strongholds for Cuban tourism by virtue of the excellent quality of their beaches of coral origin and their almost intact nature." (Op. Cit.)

Trinity. - "The city of Trinidad is located in the center of the island, in the province of Sancti Spiritus. Trinidad is one of the first towns founded in Cuba (in 1514), declared by UNESCO as Cultural Heritage of Humanity and where the architecture and the colonial air have best been preserved on the island, which is why it is also known as City Museum of the Caribbean Sea. In reality, it is one of the most charming and magical cities in the entire Caribbean and Latin America. In its surroundings, of great natural beauty, is the Valle de los Ingenios, also a World Cultural Heritage Site, El Ancón beach, located a few kilometers away, and the Sierra del Escambray, a true ecological paradise and destination of nature, also with important cultural and historical values". (Op. Cit.)
Hundred fires. - "The City of the Sea, Cienfuegos, is undoubtedly the most beautiful city in Cuba. Located in the south-central part of the country, on the margins of Jagua Bay, it was founded by French people from Louisiana in 1819. In it you can admire parks, theaters, churches, cemeteries full of valuable sculptural monuments, architectural jewels such as the Palacio de Valle and the Terry Theater and various other buildings that surround the José Martí Park, in the center of the city." (Op. Cit.)

Baracoa.- "The first city of Cuba is Baracoa, the first town in the country was founded by Diego Velázquez in 1511 at the eastern end of the island. The physical isolation in which it was kept for 4 centuries and an exuberant nature give it a unique air on the island. The original layout of the town is maintained, as well as its own dance-culinary manifestations and a wooden architecture unparalleled in the country. In addition to the beautiful natural environment that is enjoyed in Baracoa in which the Miel and Toa rivers (the largest in Cuba) stand out, the existence of good beaches a short distance from the urban center and the rich flora and fauna, the city has an intrinsic appeal and invaluable cultural and historical values" (Op. Cit.)

Viñales Valley.- "It is a magnificent destination both for nature lovers and for those interested in the cultural aspects of a region or the agrocultural part of typical crops of western Cuba such as tobacco. You can go horseback riding, dozens of trails of different themes with or without guides, visit tobacco plantations, see closely the lifestyle of the Cuban peasant or, simply, sit at the Tapas Bar to enjoy a cold beer. or a mojito and relax watching the hustle and bustle in the tranquility of this small town" (Op. Cit.)

\section{Findings and Discussion}

Although, in territorial terms, it is considered that the Republic of Cuba has a wide tourist offer, in the territorial extension, it can be observed that there are some spaces with tourist potential that have not been used to increase the offer and generate regional integration, in the search to generate greater economic dynamism, based on tourism, in the target region. 
Figure 1 graphically shows what has been said previously, if the southern part of the island is observed, the above expressed is evident, in view of this it is proposed that the tourist potential of the province of Las Tunas be detonated, see Figure 2, with which the tourist offer in the south of Cuba would be distributed, thereby achieving the regional economic integration of one more province to the tourist dynamics.

Another place that is considered with potential, within the province of Cienfuegos, and taking advantage of the tourist positioning that the city already has, is the municipality of Las Lajas, which is located a few kilometers from the tourist city of Cienfuegos and can be achieve regional integration from the tourist links that are linked between both cities, which has different potentialities within cultural tourism; This, considering that the highway that passes through the city of Cienfuegos, passes through the city of Santa Isabel de las Lajas. see Figure 2 .

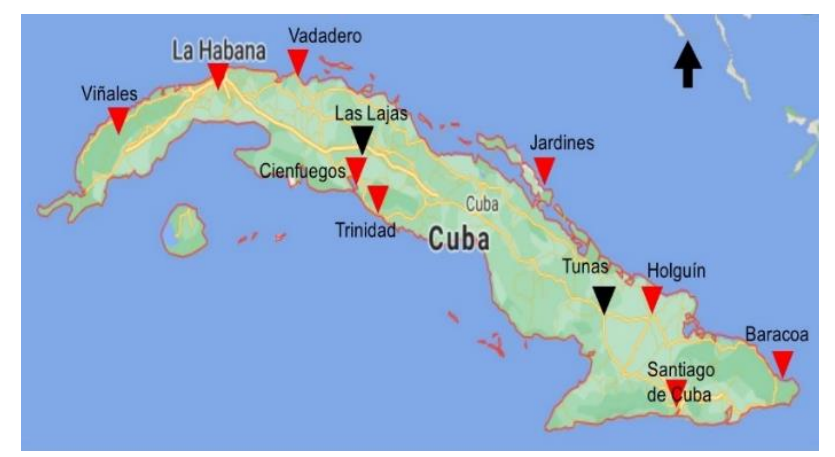

Figure 2 Regional strategic location of the tourism integration proposal for the province of Las Tunas and the city of Las Lajas, triangles in black

Source: Own elaboration with data from: HiCuba and GoogleMaps

\section{Characterization of the province of Las Tunas}

Las Tunas, border province between the central and eastern regions (see annex 1). It limits to the West with the Province of Camagüey, to the East with the Province of Holguín; to the south with the Province of Granma, to the north it has coasts that are bathed by the Atlantic Ocean and to the south by the Gulf of Guacanayabo. Province that has 8 municipalities of them three in the southern area (Amancio Rodríguez, Colombia and Jobabo), 2 in the center (Las Tunas and Majibacoa) and 3 in the northern area (Manatí, Puerto Padre and Jesús Menéndez).

\section{Location}

It is located at Latitude: $20^{\circ} 57$ ' 25 "North and Longitude: $76^{\circ} 57^{\prime} 13^{\prime \prime}$ West. Its altitude above sea level is $90 \mathrm{~m}$, its distance N-S is $63 \mathrm{~km}$ and E-W $91 \mathrm{~km}$ approximately.

\section{Communication channels}

Due to its strategic location at the entrance to the East of Cuba, Las Tunas is crossed by the highway and the central railroad, the most important routes in the country. The city is also an important road junction that links it with the other municipalities of the province.

\section{Roads}

- Carretera Central (connects with the neighboring provinces of Camagüey and Holguín).

- Las Tunas - Bayamo Highway.

- $\quad$ Highway Las Tunas - Puerto Padre.

- $\quad$ Las Tunas - Jobabo Highway.

- $\quad$ Las Tunas - Manatí Highway.

Railways

- Central railroad: Trains travel in the eastwest flow.

- $\quad$ Railroad Las Tunas - Holguín

- $\quad$ Railroad Las Tunas - Manatí

- $\quad$ Las Tunas railroad - Jesús Menéndez

Air Transport

- $\quad$ Hermanos Ameijeiras National Airport. 


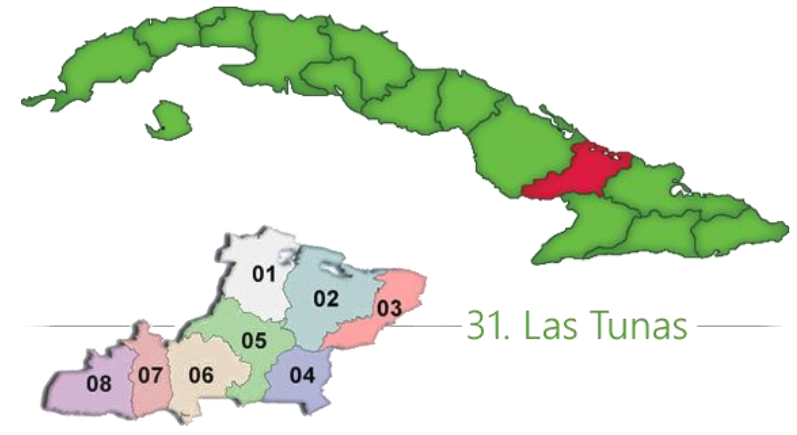

01. Puerto Padre.

02. Manatee.

03. Jesus Menéndez.

04. Majibacoa.

05. Las Tunas (provincial capital).

06. Jobabo.

07. Colombia

08. Amancio Rodríguez.

Figure 3 Map of Cuba, Las Tunas and their municipalities. Source: Municipalities of Las Tunas

\section{Background}

The arrival of Europeans to Cuba takes place in Cayo Bariay, a point close to the current territory of Las Tunas, so this territory was one of the first explored by Christopher Columbus. The exploitation to which the original inhabitants of Cuba were subjected led to their extinction, according to Castro et al. (2010) in 1521 the first shipment of African slaves to Cuba was authorized with the aim of exploiting the largest gold mine in Cuba that was located in the current municipality of Jobabo in the Las Tunas province, this was the first economic activity of the current territory after the arrival of the Iberians.

The first herd founded in the current territory according to Fernández et al. (2007) was the Herd of Las Tunas, in 1603. The name of Las Tunas, comes from the fact that in this first herd founded the species of xerophytic plants popularly known in Cuba as Tunas (Nopal in Mexico) abounded. There are records that in 1775 the main settlement was named San Gerónimo de las Tunas and the official foundation was given in 1796, although the title of town was granted in 1849 and that of city in 1853. Similarly In this way, several herds emerged, which increased agricultural production, while agriculture was for the internal consumption of the territory. By the end of the 18th century, interregional trade increased due to its favorable geographical location, agricultural production also increased, but livestock continued to be the main economic activity.
In the $19^{\text {th }}$ century, according to Castro et al. (2010), the Cuban economy is heading towards an increase in sugar production, due to the rise in the prices of this product. This became the first economic line on which the country would depend in the mentioned century and much of the next, but the current region of Las Tunas continued to be basically livestock, agriculture and mining was also carried out, but by this date copper It was what was being exploited in the area then named San Miguel de Manatí, specifically in the lands surrounding the hill and hamlet of Dumañuecos, although it was an abundant mine, its exploitation was not very durable since the extraction gallery collapsed and they were trapped in its rubble more than 100 workers of Chinese origin.

The territory that the current province of Las Tunas occupies was linked to the struggles for the independence of the island since its inception (1968), starting with the organization of the struggle and then being a battlefield, essentially its main town (Las Tunas) It was taken several times by the Mambisa forces, which, unable to keep them under their control, set fire to it on several occasions, with a high cost of lives and for the economy. On August 16, 1869 , the city took the name of "Victoria de Las Tunas" since in a combat where the independentistas had practically taken the city, they decided to withdraw, which the Spanish troops assumed as a victory and renamed the city with this name. The ten-year war culminated in 1878, without achieving the independence of Cuba from the Spanish crown, the reconstruction began and by 1885 the reconstruction of the city of Las Tunas concluded, the families returned and the economy began his gradual recovery, in his traditional activities; livestock, agriculture, some commerce and small industries.

In 1895 the struggle for national independence was resumed, in this independence feat the region of Las Tunas once again suffered the devastating effects and once again the main town of Victoria de Las Tunas was devastated and practically abandoned. In 1898 the triumph of the Cuban independence troops over the Spanish ones was imminent, then the North American intervention occurred that frustrated the total independence of Cuba. In this way, Cuba is liberated from Spanish oppression and a new stage begins, the neocolony. 
According to Castro et al., (2010), the entry of North American capital into Cuba is happening before the military intervention of the late nineteenth century, at the time of the intervention there was already a great dominance of the Cuban economy by the United States, which is consolidated with the dominance political achievement from the military occupation. On the other hand, González (1996) expresses that North American capital actively influenced the organization of the Cuban economic space and the formation of the territorial imbalances that characterize it today. From this new stage, where the economy becomes totally controlled by the United States, the priority for the Las Tunas economy becomes the sugar, fruit and mining agribusiness.

At the end of the first quarter of the $20^{\text {th }}$ century, as Castro et al., (2010), the sugar industry became the main economic activity in Las Tunas, and in the second quarter of the 20th century its economy was marked by the negative impact of the crisis of 1929, due to the decrease in sales and Sugar prices, being an economy dependent on this industry, the effect is reflected in the economy and society in general, with negative effects on family income. Despite the favorable situation shown by the economy of the territory before the crisis of 1929 , according to Castro et al., (2010), social conditions were not manifested in the same proportion, there was a high rate of unemployment, inequality, illiteracy, low health coverage, a high level of corruption coupled with other evils such as games and vices, as well as the development of gangsterism and gangs. The historical context propitiated the conditions for the struggle for independence, which was obtained on January 1 , 1959. In this way, a new stage begins that has had great repercussions on the transformation, positive, but not absent. obstacles, difficulties and mistakes, not only in the Las Tunas region but also in all of Cuba, the Cuban Revolution.

In 1959, the current province of Las Tunas was made up of various towns that at that time belonged to the province of Oriente or, failing that, to the province of Camagüey. With the new administrative political division implemented by the revolution in 1976, the current province was created, whose territory was made up of 8 municipalities thereafter (Image III).
Starting in 1959, the revolutionary government implemented measures of great social impact, health and education became sectors totally controlled by the State. In the same way, the new government promoted measures that allowed the State to take control of the Cuban economy, according to González (1996) a process of planning the economy for the industrialization of the country began, there is a process of increase in investments with this objective in the period 1976-1980. The development of the tourism sector was not a priority of the new government.

Gradually, according to Fernández et al. (2007), there was a growth in the investment process in the territory of Las Tunas, which included, in addition to the sugar industry, various branches of the economy. Some of these were the new Majibacoa sugar mill, the Glass Container factory, the Metallic Structures Company, among others. The investment policy applied, during the period 1965-1988, led to the emergence of 54 important companies in the territory, thus diversifying the economy of the region.

In the case of the Las Tunas region, despite the increase in the number of industries, commercial production, in 1989 according to González (1996) was ranked 12th among the 14 Cuban provinces existing at that time. The structure of commercial production by sectors in that year in the Las Tunas territory was as follows; industry $60.4 \%, 10.6 \%$ in agriculture and forestry, $17.6 \%$ construction, $10.7 \%$ transport and communications and $0.7 \%$ other productive activities. Despite the development gap between the Las Tunas region and the central and western provinces, and fundamentally with the country's capital, the socio-economic measures implemented by the revolutionary government made it possible to improve social indicators in Las Tunas.

Mesa-Lago (2012) argues that the actions implemented by the new government and the economic support they had from donations and loans from the Soviet Union, between 19601990, led to high social development in Cuba, which placed the country at the end of this period as one of the Latin American countries with the best social indicators. 
Since the collapse of the Soviet Union and due to the dependence and interrelation of the Cuban economy with that of this block of socialist countries, a profound economic crisis has occurred since 1990. According to MesaLago (2012) in the period 1990-1994, GDP fell by $35 \%$, this due to the decrease in industrial and agricultural activities, which were affected by the lack of fuel, inputs, spare parts and the decrease in exports and imports.

González (1996) summarizes the period 1989-1994, in terms of the behavior of the main economic activities, as a stage where agricultural, livestock, sugar and nickel production decreases. The answer was the implementation of measures, essentially in 1993, such as the introduction of foreign capital to increase the tourism and oil sector; in the same way, due to this measure, the recovery of telephony, mining, perfumery, cement, food and textiles begins.

It is this context of crisis that gives rise to international tourism in Cuba and Las Tunas, becoming the driving force behind the Cuban economy. In this period the first tourist facilities in the province emerged, firstly, the Hotel Las Tunas (in the city of Las Tunas) and later the Hotel Bisas Covarrubias (on the north coast), more recently the Hotel Cadillac (in the main city). The Cuban government has stated that the development of the tourism sector continues to be a priority for the country's economy, this is reflected in the guidelines of economic and social policy established in the VII Congress of the Communist Party of Cuba (2017).

Currently, the tourism sector has a territorial delegation from the Ministry of Tourism that manages hotel facilities (those mentioned above) and extra-hotel facilities (commercial companies, gastronomy, transporters, travel agencies, tourist training school, travel agency). employment) in the territory. In addition, there is accommodation in private houses, known as rental houses, at the end of March 2017 in the city of Las Tunas there were a total of 188 rental houses, of which 21 are fully rented and 167 are rented by bedrooms. These 188 houses offer a total of 321 rooms. The gastronomic activity is also represented in the private activity with 16 restaurants at the end of 2017.
The housing capacity available in the territory is given by 142 rooms of the state hotels of the city, 180 rooms of the Hotel Covarrubias (sun and beach) and 321 rooms of the rental houses for a total of 643 rooms.

\section{General data}

According to ONEI (2019), the province of Las Tunas has 535335 inhabitants of its eight municipalities the main municipality (Las Tunas) is the one with the largest population with 211596 (see Annex 2).

\section{Hydrological data}

The province of Las Tunas has five main rivers: (1) the Sevilla River located on the southern slope with a length of $57.0 \mathrm{~km}$; (2) the Jobabo river located on the southern slope, $66.1 \mathrm{~km}$ long; (3) River Tana located on the southern slope, $68.9 \mathrm{~km}$ long; (4) the Chaparra river located on the north slope with $22.6 \mathrm{~km}$ in length and the (5) Yariguá river located on the north slope with $62.0 \mathrm{~km}$ in length. The reservoirs of the province, Juan Sáez, Las Mercedes, Gramal, Ciego and Yariguá.

The main coastal geographical areas are:

- Bays: Puerto Padre, Malagueta, Manatí, New Grandes.

- $\quad$ Ensenadas: La Herradura (one of its main ones).

Points: Covarrubias, Brava, Roma, Uvero, Jesús, Malagueta, Piedra, Mojacasabe, Corúa, Tana, Tomate, Sevilla.

- The beaches will be addressed in the tourist potential section.

\section{Physiographic data}

The plains predominate; to the north, the northern and southern plains of Camaguiey- Las Tunas, in the northern plains are the hills of Caisimú, Dumañuecos, Cerro Verde, and Jengibre hill. The highest elevation is the heights of Cañada Honda with 219 meters high. Brown, ferralitic, hydromorphic and vertisol soils predominate. 


\section{Tourism potential}

\section{Natural attractions}

Keys: Juan Claro, Puerco, Guincho, Largo, Burro, Iguana, Sevilla, Romero, Rabihorcado.

Beaches: In the north of the province of Las Tunas there are several beaches of fine white sand that have great potential to be used in the development of tourism (see table 1).

\begin{tabular}{|c|c|c|c|c|c|}
\hline \multirow{2}{*}{$\begin{array}{c}\text { Beaches } \\
\text { with tourist } \\
\text { potential }\end{array}$} & \multirow{2}{*}{$\begin{array}{c}\text { Location } \\
\text { (Municipality) }\end{array}$} & \multirow{2}{*}{$\begin{array}{c}\text { Approximate } \\
\text { length }\end{array}$} & \multicolumn{2}{|c|}{ Characteristics } & \multirow[t]{2}{*}{ Access } \\
\hline & & & Surf & Sand & \\
\hline $\begin{array}{l}\text { The Boca de } \\
\text { Manatí }\end{array}$ & sea cow & $0.13 \mathrm{Km}$ & $\begin{array}{r}\text { No } \\
\text { waves }\end{array}$ & $\begin{array}{l}\text { Fine } \\
\text { and } \\
\text { white }\end{array}$ & No road \\
\hline 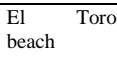 & sea cow & $3.0 \mathrm{Km}$ & $\begin{array}{r}0-0.25 \\
\mathrm{~m}\end{array}$ & $\begin{array}{l}\text { Fine } \\
\text { and } \\
\text { white }\end{array}$ & No road \\
\hline Clapper * & sea cow & $0.25 \mathrm{Km}$ & $\begin{array}{r}\text { No } \\
\text { waves }\end{array}$ & $\begin{array}{l}\text { Fine } \\
\text { and } \\
\text { white }\end{array}$ & No road \\
\hline $\begin{array}{l}\text { Covarrubias } \\
*\end{array}$ & Puerto Padre & $2.5 \mathrm{Km}$ & $\begin{array}{r}0-0.25 \\
\mathrm{~m}\end{array}$ & $\begin{array}{l}\text { Fine } \\
\text { and } \\
\text { white }\end{array}$ & With road \\
\hline The Jíbara & Puerto Padre & $0.13 \mathrm{Km}$ & $\begin{array}{r}\text { No } \\
\text { waves }\end{array}$ & $\begin{array}{l}\text { Fine } \\
\text { and } \\
\text { white }\end{array}$ & $\begin{array}{l}\text { With } \\
\text { embankment }\end{array}$ \\
\hline $\begin{array}{l}\text { The Mouth } \\
\text { of Puerto } \\
\text { Padre * }\end{array}$ & Puerto Padre & $0.9 \mathrm{Km}$ & $\begin{array}{r}\text { No } \\
\text { waves }\end{array}$ & $\begin{array}{l}\text { Fine } \\
\text { and } \\
\text { white }\end{array}$ & With road \\
\hline La Llanita * & Puerto Padre & $0.5 \mathrm{Km}$ & $\begin{array}{r}0-0.25 \\
\mathrm{~m}\end{array}$ & $\begin{array}{l}\text { Fine } \\
\text { and } \\
\text { white }\end{array}$ & With road \\
\hline Corella Point & Puerto Padre & $0.9 \mathrm{Km}$ & $\begin{array}{r}0.25- \\
0.50 \\
\mathrm{~m}\end{array}$ & $\begin{array}{l}\text { Fine } \\
\text { and } \\
\text { white }\end{array}$ & With road \\
\hline
\end{tabular}

Table 1 Main beaches in the north of the province of Las Tunas with potential for tourism development Source: Own elaboration

\section{Cultural attractions}

There are various cultural attractions that can be used depending on the tourism in the territory. The capital municipality (Las Tunas) is one of the most potentialities, its main attraction is its culture where elements of its folklore converge with museums and historical cultural manifestations. Its architecture, sculptures, cultural events and a rich tradition of legends stand out. Its architecture is eclectic, since in its buildings various styles coexist harmoniously such as Art Deco, rationalism and some traces of colonial architecture, the latter was greatly affected during the Colonial Wars of Independence. Among its most significant elements is the sculptures, so much so that it is known as the city of sculptures, since one of the greatest Cuban sculptors is home to it and contains a large number of sculptural works. Cultural events represent great potential, although it should be noted that they have lost quality and scope, for example, the Jornada Cucalambeana no longer has international participants in all its editions.

\section{Main events:}

- Cucalambeana Day; national and international in some years, in honor of the bard Juan Cristóbal Napoles Fajardo (El Cucalambé). It has an annual periodicity and consists of a week where the main songs (mainly the tenth) and folk dances of the region are exposed.

- Magic Day (Amphora). It has an annual frequency, the main magicians of the country meet to show their art.

\section{Popular carnivals.}

Legends: The city has several legends that, although they have some artistic works that refer to them, are not being used in the promotion and show to visitors. As examples the legend of the headless horseman and the legend of Majibacoa.

It is considered that there should be greater integration, both in the promotion and in the execution of the offer of cultural elements, which should be linked to the history of the city. Specifically in the design of products that include tours that highlight the link between history-architecture-legends and that take advantage of events (which must rescue their splendor of yesteryear) to intentionally show the elements described above.

\section{Inhabitants' perception of tourism development}

The population of the province of Las Tunas has the perception that the tourism development of their province is miniscule. The tourist activity is accepted by its residents because they consider that their communities can benefit from it. In the same way, the community is interested in integrating into tourism projects from their conception due to the belief that they will benefit economically with tourism development, since they assume that it will translate into employment options, income derived from the tourism sector and investment and business opportunities.

In the case of social and cultural benefits, they are interested in increasing recreational activities, improving services and public infrastructure, as well as the inspiring effect on social change.

CAMELO-AVEDOY, José Octavio, RODRÍGUEZ-ALVAREZ, Nely, MERCADO-PUPO, Yoandris and REYERO-NIETO, Roberto Fidel. Cuba: characterization of two provinces with tourism potential for regional economic development. Case. Cienfuegos and Las Tunas. Journal of Social Researches. 2021 
The inhabitants of the province of Las Tunas consider, in general, that the fact that their province is not at the level of economic development of other provinces of the country is due in part to the fact that tourism has not developed. Due to the characteristics of the province, in terms of the beauty of the beaches of the north coast, residents consider sun and beach tourism should be developed.

\section{Characterization of the province of Cienfuegos}

\section{The city of Cienfuegos}

On January 1, 1819, Infantry Lieutenant Colonel Juan Luis Lorenzo De Clouet, proposed the founding of the town of Cienfuegos, to the Governor of the Island, Don José Cienfuegos and to the Mayor Don Alejandro Ramírez, whose proposal was accepted and formalized on 9 March 1819. On April 22, 1819, in the center of the current Parque Martí, Don Luis De Clouet took possession of the land on behalf of His Majesty the King of Spain. It is the only Cuban city that was founded by the French and was called: Colonia Fernandina de Jagua (Ministry of Tourism of Cuba, 2018).

It is also known as La Perla del Sur or La Linda Ciudad del Mar. Its historic center and the Punta Gorda protection zone was classified as a World Heritage Site on July 15, 2005, "a condition obtained by being the first and exceptional example of an architectural ensemble representative of the new ideas of modernity, hygiene and order. In the urban planning of the Latin American 19th century, to this is added a Protection Zone, qualified by its high environmental, architectural and cultural values, ranging from the end of Paseo del Prado to the area known as La Punta (Ministry of Tourism of Cuba, 2018).

In 1829 it reached the title of Villa de Cienfuegos, in honor of José Cienfuegos, Captain General of the Island at the time of its foundation. It acquired the title of city in 1880 , due to the accelerated economic development achieved at that stage. The city has valuable properties, and what predominates in it is the good state of conservation of the urban complex, in which symmetry, proportionality and the use of decorative elements of the classical formal code are appreciated.
Domes, pediments, lookout towers and ornaments stand out, complementing an architectural task that is distinguished by its sobriety, elegance and good constructive taste. It has a cultural wealth characterized by folk dances, singing, painting, as well as natural attractions such as beaches, mountains, rivers and caves (Ministry of Tourism of Cuba, 2018).

\section{Characteristics of the province of Cienfuegos, Cuba}

The province of Cienfuegos has a surface area of $4,188.61 \mathrm{~km}^{2}$, being one of the three smallest in the country, it has a population of 407,244 inhabitants and a population density of 97.2 inhabitants $/ \mathrm{km}^{2}$. The province is located in the center-south of the island, at coordinates 21021 'and $22035^{\prime}$ 'north latitude and 80020 'and 810 10 ' west longitude. To the north it limits with the municipalities of Ranchuelo and Santo Domingo, belonging to the province of Villa Clara and with the municipalities Calimete and Los Arabos, of the Matanzas province. To the east it borders the municipality of Manicaragua, also in the province of Villa Clara and with the municipality of Trinidad, which belongs to the province of Sancti Spíritus. On the southern part it borders the Caribbean Sea and to the west with the municipalities Ciénaga de Zapata and Calimete, which are part of the province of Matanzas (National Office of Statistics and Information [ONEI], 2019).

In the western and central portion of the province the great plains predominate, towards the North the relief is undulating, towards the east it is mountainous due to the presence of the mountains of Trinidad, where the highest elevation of the province is located, the Pico San Juan with 1150 meters of height on the level of the sea. To the south, the relief is outlined by the Caribbean Sea, with abrasive and cumulative coasts, combining with inlets and natural pools on rocky coasts with sandy beaches (ONEI, 2019 , p.7). The climate is influenced by the proximity to the mountains of the Guamuhaya Mountain Massif, to the East, and the Caribbean Sea that borders the entire southern part of the Province. Six climatic zones are identified, and technically a cool profile has been established between November and April and a hot one between May and October. The average annual temperature is $24.5{ }^{\circ} \mathrm{C}$, the relative humidity $77 \%$ and the average annual rainfall is $1304 \mathrm{~mm}$. (ONEI, 2019, p.7). 


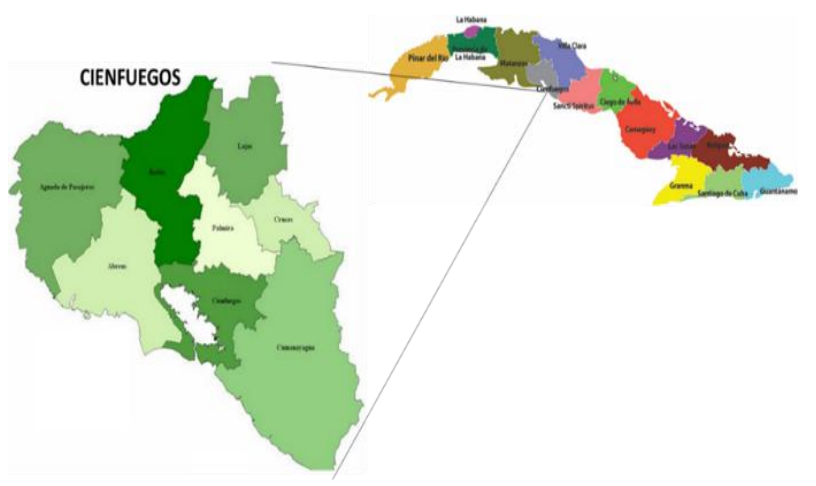

Figure 4 Location of Cienfuegos, Cuba Source: Own elaboration

\section{Cienfuegos as a tourist pole}

As mentioned above, the province of Cienfuegos has various characteristics that make it an attractive tourist area, so both national and international tourist demand is very high. National tourism comes from all the regions of the country that visit it to know its cultural richness and enjoy its beaches, mainly. As for international tourism, several of the existing tourism modalities are demanded such as: sun and beach tourism, hiking, cultural and heritage tourism and health tourism. The main countries that bring tourists to the island are: Canada, Germany, France, United Kingdom, Spain, Switzerland, Holland and Italy, mostly cold countries that travel to Cuba mainly in the months between mid-December and mid-March, as well like the months of July and August, looking for the warm climate that this region offers.

\section{Cienfuegos main tourist attractions}

Among the natural attractions of the province, the bay of Cienfuegos stands out, with an area of $88 \mathrm{~km} 2$. Its shape as a bag has made it possess one of the most important ports in Cuba and the richness of flora and fauna that can be found in its surroundings make it a spectacular place for visitors. To the east of the bay, is the Guanaroca Lagoon, an ideal place for bird watching, among which the colonies of pink flamingos, the cartacuba and the Tocororo, which is the National Bird of Cuba, stand out.

Near the city of Cienfuegos there is also the Botanical Garden, the oldest in Cuba, which also functions as a research center. The province has several beaches such as, Rancho Luna beach, where the dolphinarium is also located; the Villa Guajimico, with its diving center; Yaguanabo beach and Playa Inglés, among others.
The Guamuaya mountain range is also located in Cienfuegos, where you can see one of the most complex ecosystems in Cuba, with a great wealth of biodiversity and landscapes. There you can see the Pico San Juan, the second highest elevation in the country; the Martín Infierno cave, with a stalagmite 50 meters high, the El Nicho Natural Park, with its waterfalls and wells, places where you can go hiking.

\section{Cultural attractions}

The city of Cienfuegos has a great cultural wealth and an architecture that makes it very peculiar, being the only one in the country that was founded by the French. Several heritage sites stand out, such as: José Martí Park, in which the sculptural ensemble of the National Hero José Martí stands out, the two lions in one of its entrances, the fountains, the Glorieta, the Arco de los Obreros; as well as various busts erected in memory of relevant personalities. In its surroundings the most important constructions in the cultural, political, administrative and religious order rise. This park and its surroundings have been classified as a national monument since October 10, 1978.

The Colegio San Lorenzo y Santo Tomás is another of the buildings that attract attention, due to its size and for having been the scene of great historical, political, social and cultural events such as September 5, 1957. The Tomás Terry Theater is also a one of the beauties that the city has, it is one of the 3 vernacular theaters in Cuba. There you can see a great artistic wealth in its ceiling paintings, interior walls, mural paintings and balconies, attributed to Camilo Salaya Toro, a prominent Spanish artist established in the city during this stage.

It should also be noted the Palacio de Ferrer, a beautiful building built by the Spanish merchant and landowner José Ferrer Sirés. It is known that this place received Enrico Caruso as a guest, when he made his presentations at the Tomás Terry theater. Nearby are also the Government House and the Cathedral of Our Lady of the Immaculate Conception, sites that stand out for their conservation and beauty. 
In the area called Punta Gorda there are also several buildings that are symbols of the city, the Palacio de Valle is one of them, designed by the Cienfuegos architect Pablo Donato Carbonell and its construction was directed by the Italian civil engineer Alfredo Colli Fanconetti, where French, Italian, Arab and Cuban artisans worked. Some materials were imported from Spain, Italy and the United States and Cuban precious woods were used. The building has three levels, with a basement, and ends in three towers: one, Roman Gothic, another Indian and the third, an Arab-style minaret, which have been interpreted as symbols of love, religion and strength. It is currently considered the most luxurious restaurant in Cienfuegos.

The Cienfuegos Club is another of the buildings that stand out, it has three levels and is topped by a dome and four towers, two of them are domes and two viewpoints. It is painted in white with the domes in green, which is the sporting color of Cienfuegos. The Cienfuegos Club has two restaurants whose specialty is seafood: Restaurante Marinero (Buffet) and Restaurante Café Cienfuegos.

Cienfuegos has the longest meadow promenade in Cuba, where the statue of Benny Moré is located, a monument dedicated to this renowned singer of Cuban music, born in the Santa Isabel de las Lajas municipality, belonging to the province of Cienfuegos. At the end of the meadow is the Cienfueguero boardwalk, a place of concurrence, which functions as an excellent viewpoint of the bay.

Another of the attractions of Cienfuegos is the Tomás Acea Cemetery, considered the only cemetery - garden in Cuba and the Nuestra Señora de los Ángeles de Jagua Fortress, located at the entrance of the bay. This last building was built in 1745 with the aim of protecting the city from the entry of corsairs and pirates. Finally, you can mention a sit.

\section{Cienfuegos potential market}

Cienfuegos's target market is made up of two major segments: the national or domestic market and the international market. The first segment includes national visitors who arrive in the territory from all the country's provinces. The second segment includes international tourists who visit the province, mainly those staying at the Rancho Luna and Faro Luna Hotels.

ISSN: 2414-4835

ECORFAN $^{\circledR}$ All rights reserved.
The countries that stand out for being the ones with the highest number of visitors are: Canada, France, Germany, the United States, Italy, Spain and Switzerland, among others (Ministry of Tourism, 2018).

In the statistical yearbook of Cienfuegos, the number of foreign visitors that come to the state for months of the year can be observed, highlighting that the season with the highest influx of foreign tourists to the province occurs in the months between November and March. The main source countries of tourists to the province are also indicated, which are: Canada, Germany, France, the United States and to a lesser extent Italy and Switzerland. It would be valid to clarify that the arrival of tourists from the United States mostly refers to the community of Cubans residing in that country (ONEI, 2019).

\section{Cienfuegos tourist infrastructure}

In the country there is a group of hotel and nonhotel entities, as well as others of an autonomous nature that govern the integral development of tourism. In Cienfuegos, within the hotel companies are: Empresa Cubanacán S.A, a leading group in Cuban tourism, both in hotel and non-hotel operations. The Grupo Hotelero Gran Caribe S.A., a public limited company with legal personality and its own assets that manages and markets its own facilities or those of third parties under different modalities and brands.

Another of the companies is Horizontes, which offers and provides foreign visitors with services for the recovery of their health and rehabilitation in the physical and mental order. The Gaviota S.A. Tourism Group, whose objectives are the promotion and sale of hotel and tourist services, as well as its specializations in health, nautical, fishing, diving and other modalities. Islazul is another of the companies, it is a chain that is mainly dedicated to national tourism as well as the Business Group Campismo Popular, also dedicated to ecotourism (Ministry of Tourism, 2018).

Among the non-hotel facilities, some stand out such as: Cubatur: agency in charge of the professional organization of tourist trips to Cuba or other destinations. It also carries out receptive and tour operator services. Transtur: company that provides transportation services to international tourism by buses, minibuses, rental cars, taxis, other cars and any other means of land transportation.

CAMELO-AVEDOY, José Octavio, RODRÍGUEZ-ALVAREZ, Nely, MERCADO-PUPO, Yoandris and REYERO-NIETO, Roberto Fidel. Cuba: characterization of two provinces with tourism potential for regional economic development. Case. Cienfuegos and Las Tunas. Journal of Social Researches. 2021 
Caracol: it is a chain of stores of all kinds of products that operates for both national and international tourism (Ministry of Tourism, 2018).

\section{Development plan of the province of Cienfuegos}

According to data offered by the Provincial Delegation of Tourism to the Granma newspaper (official gazette of Cuba) in 2015, the Tourism Development Plan in Cienfuegos until 2030 has contemplated the realization of a group of investments with some external financing proposals. For this, the study areas have been updated, the topographic surveys, land tenure / legalization and studies of the environmental baseline for the comprehensive development of the Rancho Luna-Punta La Milpa area (20192027) have been carried out; and Punta Barrera and Playa Inglés-La Tatagua (2020-2028). The purpose, according to the report, is to turn the territory into an integrated and strengthened tourist pole based on its potentialities, so that it can be among the most competent and attractive destinations in the south of the Cuban archipelago (Martínez, 2015).

The report itself informs that golf destinations are conceived in the perimeter between Rancho Luna and Pasacaballos, as well as in the one located from Playa Inglés to La Tatagua, with a planned area of 1,748 hectares. On the other hand, the infrastructure (villas and hotels) planned to be built proposes the increase of more than 16,000 rooms, with a density of 31 of them per hectare. There is also a proposal for external financing and conciliation with the National Sports and Recreation Institute (Inder), to execute a funicular water park in the La Punta area (in the bay of Cienfuegos) in the space of only two years; and the cruise terminal (to be erected by the Ministry of Transport), in line with the launch of this modality here (Martínez, 2015).

Similarly, it was reported that among the objectives of the sphere of tourism is the expansion of the Rancho Luna hotel and a project in Cayo Carenas.
The reconversion of a large group of facilities in hotels of the "Encanto" chain is another of the purposes and the hotel plant should grow with new constructions (not belonging to the Encanto hotels) such as the Compact, with 300 rooms; Mar 1 and 2, with 335; Sunset, with 200; and a hotel complex in Cayo Carenas, of a similar number. On the other hand, the technical task for the Residential Nautical Village, a Class A Marina that will have 200 berths, 100 rooms and 256 apartments is already in the completion phase (Martínez, 2015).

\section{Inhabitants' perception of tourism development}

The arrival of tourists, especially foreigners, to the province of Cienfuegos and its increase since its declaration as Cultural Heritage of Humanity, in 2005, has been considered by the resident population as a positive element for the socioeconomic development of the province. Tourism activity is perceived as a stimulus for the conservation and repair of heritage sites, the construction of recreational areas, has promoted the training and implementation of both technical and university careers in the area of tourism.

On the other hand, as of 2011, with the celebration of the VI Congress of the Communist Party of Cuba (PCC), the guidelines of the economic and social policy of the country were approved, where cooperative, mixed ownership is recognized, among others. and the private sector of Cuban or totally foreign natural or legal persons, where they all interact as a whole. This has led to a broad development of some private sectors, mainly the accommodation and gastronomy sectors, where the capacity for accommodation and providing food services is much broader than in the state sector.

Another positive aspect that stands out is that precisely because the accommodation capacity is greater in the private sector, this is carried out in rooms that are often part of the main building of the houses and the tourism that visits Cienfuegos, generally it is a tourism that is interested in living with the resident population and consuming local products. The negative effects that these neighborhoods can bring with them, such as transculturation processes and prostitution, among others, are still recognized, although these have been strongly combated by local and national authorities.

CAMELO-AVEDOY, José Octavio, RODRÍGUEZ-ALVAREZ, Nely, MERCADO-PUPO, Yoandris and REYERO-NIETO, Roberto Fidel. Cuba: characterization of two provinces with tourism potential for regional economic development. Case. Cienfuegos and Las Tunas. Journal of Social Researches. 2021 


\section{Conclusions}

The emergence of international tourism in Las Tunas is produced from measures implemented in the 90s as an alternative to boost the economy to counteract the negative effects of the economic crisis. At present, tourism development continues to be a proposal for the government, so it needs to be detonated with higher priority.

There is potential for the development of the tourism sector in the province of Las Tunas, both in sun and beach tourism in the north, and in the city, the latter mainly in the main city.

The community considers that tourism in the territory of Las Tunas is not developed, that the economic backwardness compared to other regions of the country is due to the scarce tourism in the territory. The population assumes that tourism will benefit them since it is an employment opportunity, income derived from the tourism sector, investment opportunities, business and a driver of social indicators.

The province of Cienfuegos, being in the center of the country, has a privileged position, being an obligatory passage for people who travel from one end of the island to the other. This has represented a great opportunity for the implementation of tourism in this region of Cuba, to which should be added the extraordinary geographical conditions that it has, with a great variety of ecosystems ranging from marine, coastal, mangrove, mountain, among others and the great cultural and patrimonial wealth that the city of Cienfuegos possesses.

The Tourism Development Plan in Cienfuegos until 2030 has contemplated, as has been seen previously, the realization of a large group of investments, ranging from hotels to golf courses. This will require carrying out multidisciplinary studies that allow evaluations to be made, but, above all, that take into account the perception of risk, both natural and social in nature.

Sustainable Regional Development is something that the entire island must implement in order to preserve economic activity in the long term, regardless of any of the economic branches in question; the size of the island urges it to take care of its natural resources and its territory to achieve sustainability and sustainability of social improvement.

ISSN: 2414-4835

ECORFAN ${ }^{\circledR}$ All rights reserved.

\section{References}

Camelo, O. (2017). Ensayo sobre la evolución del sistema económico y las nuevas formas de integración de las regiones económicas. En: Ramírez, Espinoza, Chávez y Márquez. Economía y conocimiento para el desarrollo regional sustentable. Pág. 39-66. Edit. UdGUAN. México.

Castro, O., Hernández, S., y Gutiérrez, A. (2010). Historia Económica de Las Tunas hasta 1959

https://www.eumed.net/cursecon/ecolat/cu/201 0/ags.htm

Chiavenato Idalberto (1999). Administración de recursos humanos. Edit. McGraw Hill.

Chiavenato Idalberto (2009). Gestión del talento humano. Edit. McGraw Hill.

CubaAhora. Economía, habitaciones turísticas cubanas.

Url:

https://www.cubahora.cu/economia/habitacione s-turisticas-cubanas-una-cifra-que-creceinfografia\#: :text=de\%20este\%20organismo.,Cuba\%20cuenta\%20actualmente $\% 20$ con $\% 20 \mathrm{u}$ na\%20planta $\% 20$ hotelera $\% 20 \mathrm{de} \% 20 \mathrm{~m} \% \mathrm{C} 3 \% \mathrm{~A}$ 1s\%20de,de\%20104\%20mil\%20en\%202030.

Datos expansión (2021). Cuba: economía y demografía 2021. Url: https://datosmacro.expansion.com/paises/cuba

Fernández, P., Cardoza, J., Avalo, R., Rad, J., y Garrido, R. (2007). Las Tunas a través del tiempo (Sanlope, Ed.).

González, R. (1996). Las actividades económicas en Cuba. Estudios Geográficos, 57, 269-289.

http://estudiosgeograficos.revistas.csic.es/index. php/estudiosgeograficos/article/view/666/710

Heiler, W. (1969). Diccionario de economía política. Edit. Labor. España.

HiCuba. Principales destinos Turísticos. Url: https://www.hicuba.com/destinos.htm

Labruneé, M. (2018). Crecimiento y desarrollo. Edit. Universidad Nacional de Mar del Plata. Argentina. 
Lineamientos de la Política Económica y Social del Partido y la Revolución para el período 20162021,

http://www.granma.cu/file/pdf/gaceta/Lineamie ntos\%202016-

2021\%20Versi\%C3\%B3n\%20Final.pdf

Martínez, J. (10 de mayo de 2015). Cienfuegos planifica su desarrollo turístico. Granma. Recovered from: http://www.granma.cu/cuba/2015-05-

10/cienfuegos-planifica-su-desarrollo-turistico

Marx, C. (2010). El capital tomo I. Edit. FCE. México.

Mesa-Lago, C. (2012). Sistemas de protección social en América Latina y el Caribe: Cuba. http://repositorio.cepal.org/handle/11362/4034

Ministerio de Turismo de Cuba. (2018). Infotur Cienfuegos. Recovered from: https://www.cuba.travel/destinos/cienfuegos

Oficina Nacional de Estadística e Información. (2019). Anuario Estadístico 2018 Cienfuegos. Recovered from: http://www.one.cu/aed2018/27Cienfuegos/13\% 20Turismo.pdf

ONEI. (2019). Anuario estadistico de Cuba. Capitulo $1 . \quad$ Territorio ONEI. http://www.onei.gob.cu/node/14748

Samuelson, P. (1983). Economía. Edit. McGH. México.

Sandoval, Luis (2008). Los ciclos largos de la coyuntura económica, traducción de la obra de Nikolai Dmitrievich Kondrátiev. Edit. UNAM. México.

UNAM (s/f). Beneficios Sociales. Url: https://archivos.juridicas.unam.mx/www/bjv/lib ros/3/1444/3.pdf
CAMELO-AVEDOY, José Octavio, RODRÍGUEZ-ALVAREZ, Nely, MERCADO-PUPO, Yoandris and REYERO-NIETO, Roberto Fidel. Cuba: characterization of two provinces with tourism potential for regional economic development. Case. Cienfuegos and Las Tunas. Journal of Social Researches. 2021 